АНТИСИПАТИВНИЙ МАРКЕТИНГ ЯК МЕХАНІЗМ ІДЕНТИФІКАЦІЇ ПОТРЕБ
СПОЖИВАЧІВ ПРОДУКЦІЇ АВТОМОБІЛЕБУДВНИХ ПІДПРИЄМСТВ

\title{
ANTISIPATIVE MARKETING AS A MECHANISM FOR IDENTIFYING THE CONSUMER NEEDS OF AUTOMOTIVE ENTERPRISES PRODUCTS
}

\section{УДК 658.8}

DOI: https://doi.org/10.32843/infrastruct54-18

\section{Куриляк О.М.}

аспірант

Національний університет

водного господарства

та природокористування

Kuryliak Oleksii

National University

of Water and Environmental Engineering
У статті розглянуто основні особливості розвитку ринку автотранспортних засобів, сутність антисипації та роль антисипативного маркетингу у процесах задоволення потреб споживачів. Висвітлено роль галузі автомобілебудування для економіки держави та виокремлено основні вектори розвитку автомобілебудівних підприємств в умовах цифрової трансформації. Здійснено дифреренціацію підприємств залежно від їхньої ролі у ланцюгу створення доданої вартості. Виокремлено фрактори, від яких залежить ефективність упровадження антисипативного маркетингу. Охарактеризовано ключові елементи, які здійснюють вплив на розвиток антисипативного маркетингу. Виділено особливості використання даних про споживача у прочесі реалізації цілей антисипативного маркетингу. Висвітлено характер персональної інсоормації, яку споживачі готові поширювати стороннім організаціям. Іәентифіковано детермінанти доданої иінності у процесі реалізації маркетингової стратегії. Проаналізовано тренди розвитку ринку автотранспортних засобів, які матимуть доступ до хмарних технологій.

Ключові слова: маркетинг, антисипативний маркетинг, поведінка споживачів, ринок автомобілебудування, прогнозування попиту.

В статье рассмотрены основные особенности развития рынка автотранспортных средств, сущность антисипации и роль антисипативного маркетинга в процессах удовлетворения потребностей клиентов. Освещена роль отрасли автомобилестроения для экономики государства и выделены основные векторы развития автомобилестроительных предприятий в условиях цифровой трансорормации. Осуществлена дифрореренциация предприятий в зависимости от их роли в чепи создания добавленной стоимости. Выделены фракторы, om которых зависит эфрорективность внедрения антисипативного маркетинга. Охарактеризованы ключевые элементы, которые оказывают влияние на развитие антисипативного маркетинга. Выделены особенности использования данных о потребителе в процессе реализации целей антисипативного маркетинга. Освещен характер персональной инфрормации, которую потребители готовы распространять третьим организациям. Идентисрицированы детерминанты добавленной ценности в процессе реализации маркетинговой стратегии. Проанализированы тренды развития рынка автотранспортных средств, которые будут иметь доступ к облачным технологиям.

Ключевые слова: маркетинг, антисипативный маркетинг, поведение потребителей, рынок автомобилестроения, прогнозирование спроса.

The main features of the development of the motor vehicle market in the conditions of pandemic and recession of the world economy are considered in the article. The essence of antisipation and the role of antisipative marketing in the processes of satisfying consumer needs are highlighted. The role of the automotive industry for the state economy is highlighted and the main vectors of development of automotive enterprises in the conditions of digital transformation are depicted, which include the need to ensure short-term profitability and search for long-term investments of automobile enterprises; the need to find opportunities to improve the level of consumer experience; increase attention to information security and compliance of consumer data collection and processing systems with respect to established market requirements; search for new technologies and formation of strategic partnerships with enterprises of other industries; antisyping of new opportunities depending on the life cycle of the product and the consumer; installation of new competitive business models. The differentiation of enterprises depending on their role in the value chain has been carried out, in particular, they are assigned to microenvironment, mesoenvironment and macroenvironment. The factors on which the effectiveness of anticipative marketing implementation depends are singled out. The key elements that influence the development of anticipative marketing are characterized, in particular, consumers are identified as generators of ideas and needs; the platforms on which data collection and formation of the corresponding networks is organized are allocated; the role of data as sources for the implementation of anticipative marketing programs are characterized; infrastructure is allocated as an additional element of providing data about consumers and the environment by exchanging information between "smart" devices; the type of the enterprise which depending on a profile of activity has a certain influence on identification of consumers needs is allocated. Peculiarities of using consumer data in the process of realization of anticipative marketing goals are identified. The nature of personal information that consumers are willing to disseminate to third parties is highlighted. The determinants of added value in the process of implementing a marketing strategy are identified. Trends in the development of automotive market of connected cars are analyzed. Key words: marketing, antisipative marketing, consumer behavior, automotive market, demand forecasting.

Постановка проблеми. Прогнозування потреб споживачів завжди було пріоритетним завданням будь-якого підприємства, адже розуміння потреб створює передумови для максимального їх задоволення, а отже, і забезпечення успішного фуннкціонування підприємства. Однак рівень прогнозування потреб зазвичай має значну похибку. Збір даних про поведінку споживачів, їх очікування, вподобання, стиль життя, дані, отримані 3 польових досліджень чи 3 онлайн-відстеження активності цільової аудиторії, є цінними та застосовуються у процесі розроблення комплексу маркетингу. Цінність даних збільшується за умови кваліфрікованого аналізу та ідентифрікації існуючих взаємозалежностей. Завдяки цьому покращується точність прогнозів. Однак усі окреслені дії не спроможні говорити про майбутні очікування споживачів, про їхні потреби, які можуть виникнути сьогодні, а можливо, через тиждень чи місяць, адже всі дані, які збираються, говорять про історію поведінки, а не про майбутнє, а прогнозування здійснюється, виключно базуючись на попередніх 
ситуаціях. У такій ситуації актуалізується питання антисипації очікувань споживачів, фрормування стратегій реалізації антисипативного маркетингу, який покликаний ідентифрікувати потенційні тренди чи потреби споживачів ще до їх настання завдяки глибокому і різносторонньому аналізу наявних даних, інтуїції експертів чи їх знань про ринок.

Аналіз останніх досліджень і публікацій. Проблемами розвитку антисипативного маркетингу та прогностичною аналітикою займається значна кількість науковців. Так, у роботі Р. МакКарті та Л. Халаві [1] висвітлюються особливості використання даних для реалізації прогнозної аналітики. У роботі Г. Гао-Чун та Л. Тінг-Пенг [2] досліджуються процеси використання прогнозної аналітики для забезпечення повторних закупівель споживачами. Роботи Р. Фергюсона [3] присвячено процесам прийняття рішень на підставі даних, отриманих від аналітики продажу товарів.

Постановка завдання. Метою дослідження $€$ ідентисрікація особливості розвитку ринку автомобілебудування в епоху діджиталізації автотранспортних засобів та виявлення потенціалу даних, які агрегуються автомобілебудівними підприємствами та іншими операторами на ринку в цілях реалізації антисипативного маркетингу.

Виклад основного матеріалу дослідження. Потреби споживачів, їхні цінності, особливості поведінки, лояльність до брендів, відмінності у поведінці в мережі Інтернет та оорлайн - усе це актуальні завдання, детермінація яких дає змогу підприємству здобути значні конкурентні переваги на ринку, зокрема на ринку автотранспортних засобів. В умовах карантину, викликаного пандемією COVID-19, поведінка споживачів зазнала суттєвих змін, адже будь-яка ситуація, яка є нетиповою, яка виникла вперше або ж є надзвичайно змінною, веде до зміщення поведінкових шаблонів, а тому і прогностичні моделі не здатні з високою точністю спрогнозувати подальші кроки споживачів, не говорячи вже про майбутні потреби. Історія попередніх купівель, запитів споживачів, зауважень чи рекомендацій, яка доступна завдяки традиційним CRM-системам, не спроможна за таких умов забезпечити ідентиорікацію майбутніх очікувань чи трендів, притаманних відповідному ринку. У зв'язку із цим сучасні маркетингові інструменти покликані встановити очікування споживачів та типові шаблони поведінки, що базуються переважно на онлайн-спостереженні (адже карантинні обмеження сорормували певні перепони для проведення офлайн-досліджень класичного характеру), обробці даних, зібраних із пристроїв, до яких споживачі відповідного підприємства зазвичай мають доступ, а також даних доступних від інших провайдерів послуг. Сучасні автотранспортні засоби із засобів для переміщення перетворилися на додаткове джерело даних, адже
3 появою функцій підключення автомобіля до мережі Інтернет та появою значної кількості сенсорів і датчиків створилося підґрунтя для збору даних про водія автотранспортного засобу та фрормування типового портрету споживача і шаблонів його поведінки.

Сучасний маркетинг переважно базується на даних, їх обробці та вмінні ідентиорікувати найбільш релевантні дані відповідно до поставлених завдань. Необхідно зазначити, що в еру Інтернету речей обсяги даних, які існує можливість зібрати, практично неможливо описати, їх кількість та багатогранність дають значні ресурси для ведення маркетингової діяльності, з одного боку, з іншого ж постає проблема обробки даних, піднімається питання компетенцій у процесах оперування великими масивами даних та залучення штучного інтелекту до відповідних завдань. У цьому контексті маркетингова діяльність актуалізується не з позицій ідентифікації існуючих потреб споживачів, а 3 позицій їх антисипації. Антисипативний маркетинг набуває все більшої актуальності, адже, володіючи значними обсягами інформації про споживача, його типову поведінку, вподобання, існуючі ринкові тренди, у тому числі й у суміжних галузях, фрормуються передумови для прогнозування майбутніх потреб споживачів, для розроблення товарів і послуг, які з високою ймовірністю будуть затребувані найближчим часом споживачами.

Ураховуючи роль галузі автомобілебудування, її ключову вагу у розвитку будь-якої національної економіки, необхідно актуалізувати питання антисипації очікувань споживачів автомобілебудівної продукції. Автомобілебудівні підприємства попри інноваційний підхід до розвитку як основного продукту, так і сорери його обслуговування не характеризуються значними темпами в упровадженні даних зібраних автотранспортними засобами у власних маркетингових кампаніях та у фрормуванні маркетингових стратегій. Причиною цього $\epsilon$, передусім, необхідність перебудови системи прийняття рішень, побудованої на даних. 3 іншого боку, існують також і ринкові перепони (зокрема, кількість підключених до мережі Інтернет автомобілів $€$ невеликою порівняно 3 класичними транспортними засобами) у впровадженні маркетингових рішень, виключно базуючись на базах даних, зібраних автомобілем. Попри не стрімкі темпи залучення «великих даних» у сореру прийняття маркетингових рішень, поступ у даному напрямі $\epsilon$ вимогою часу, адже саме антисипативний маркетинг та відповідні стратегії дадуть змогу в майбутньому чітко ідентифіковувати змінні очікування споживачів ще до моменту їх зміни, що на відміну від існуючих підходів (реагування на вже існуючі потреби, а не на потенційні потреби, виникнення яких матиме місце у майбутньому) стане ключовою перевагою у комунікації зі споживачем. 
Загалом в умовах цифррової трансорормації автомобілебудівних підприємств та їхньої продукції необхідно виділити декілька ключових векторів розвитку (рис. 1).

1) Ситуація з пандемією та карантинними обмеженнями, скорочення доходів населення, невизначеність та ризики втрати місця роботи спричинили зменшення попиту на автомобілі у розрізі як Європи, так і загалом у світі. Існує декілька країн (зокрема, Китай), де відбувається значний ріст попиту на автомобілі, однак загалом більшість ринків перебуває у стані спаду. За таким умов компанії змушені шукати сорери забезпечення короткострокової рентабельності, оскільки надзвичайно складно в умовах пандемії говорити про можливості реалізації довгострокових стратегій та пошуку механізмів скорочення витрат. Попри зменшення обсягів попиту на автомобілі 3 двигунами внутрішнього згоряння попит на електромобілі або на автомобілі 3 гібридними двигунами стабільно зростає. Одним із каталізаторів даного ринку $є$ державні програми з екологізації ринку автомобілебудування та надання автоскладальним підприємствам дотацій на розвиток зелених технологій у рамках виготовлення автотранспортних засобів, що створює підґрунтя для забезпечення відповідної стійкості автомобілебудівних підприємств, 3 одного боку, а з іншого - генерує вектор розвитку ринку загалом. Окрім цього, у певних країнах споживачам надаються пільгові кредити чи фрінансова допомога за умов переходу на електромобілі чи більш екологічно чисті типи двигунів. Також необхідно зазначити, що, крім електрифрікації автомобілів, відбувається їх поступова адаптація до процесів автопілотування та встановлення комплексних інфрормаційних продуктів. Даний вектор розвитку у короткостроковій перспективі $є$ затратним інвестиційним процесом, однак зі збільшенням кількості «розумних» автомобілів потенціал окупності такого роду інвестицій є надзвичайно великим. Необхідно також зазначити, що зі збільшенням обсягів даних, які збирає автомобіль у процесі переміщення, зростають можливості автовиробників для вдосконалення конструкційних особливостей автомобіля, а також підвищення його зносостійкості, що, своєю чергою, забезпечить у довгостроковій перспективі зменшення потреби в техогляді та ремонті. Ураховуючи рівень рентабельності ринку замінних частин, з одного боку, даний вектор $€$ вигідним для споживачів, однак $€$ не вигідним для автовиробника, адже кількість візитів на СТО та потреби у замінних частинах суттєво скоротяться, а обсяги продажу нових автомобілів не зможуть покрити витратну статтю автовиробників. За таких умов вектором довгострокових інвестицій повинні стати інфрормаційні

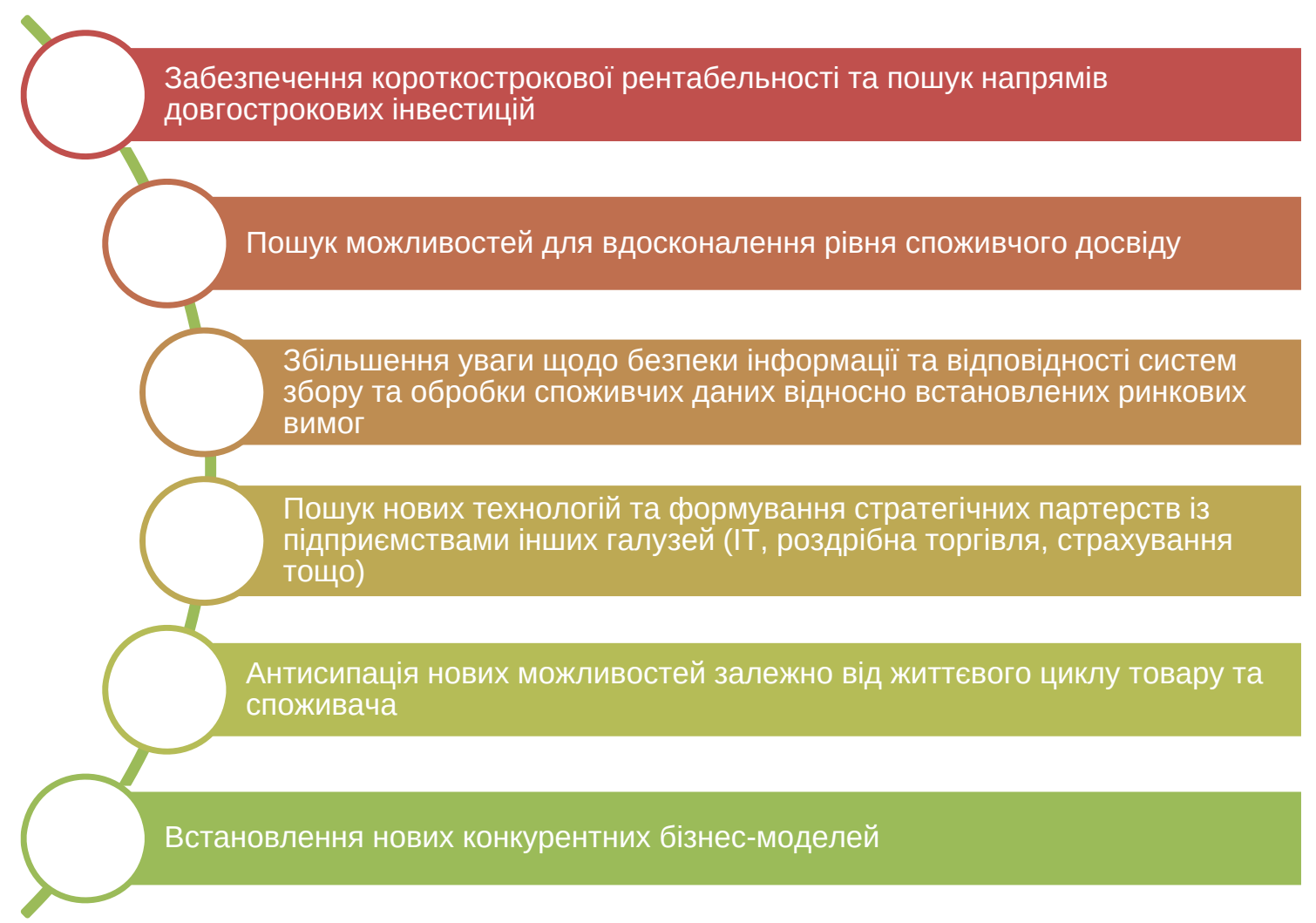

Рис. 1. Основні вектори розвитку автомобілебудівних підприємств та їхньої продукції в умовах цифрової транссоормації

Джерело: розроблено автором на основі [4] 
технології, програмні продукти, які зможуть надавати індивідуалізовані послуги із відповідними властивостями залежно від потреби споживача. Автомобілі, які матимуть можливість підключатися до мережі Інтернет, отримають доступ до автоматичного оновлення програмних продуктів, споживачі матимуть змогу залежно від фрінансових можливостей та потреб індивідуалізувати можливості автомобіля, а компанії отримають нові ресурси для забезпечення більшої рентабельності; зміна бренду автомобіля стане достатньо складним і небажаним для споживача процесом. Наведене вище додатково аргументує потребу щодо пошуку шляхів реалізації антисипативного маркетингу на шляху просування автотранспортних засобів та вбудованих інфрормаційних продуктів.

2) Наступним вектором розвитку автомобілебудівних підприємств є розвиток споживчого досвіду в контексті використання вже доступних на ринку інформаційних технологій, вбудованих в автотранспортні засоби. Попри наявність можливостей споживачі неактивно користуються відповідним фрунціоналом, адже виробники програмних продуктів до персональних комп'ютерів, телефонів чи гаджетів більш активно адаптують програмні продукти під потреби споживачів, що, відповідно, впливає і на комфрорт та простоту в користуванні. Однак така компанія, як «Тесла», генерує попит на відповідні продукти й ефективно конвертує зусилля з упровадження інорормаційних продуктів.

3) Зі збільшенням обсягів інформації, яка збирається про споживача, зростають потреби у безпеці відповідних даних. Має місце тісна кореляція між обсягом поширення інорормаційних технологій та наявністю ефективних алгоритмів безпеки.
Споживачі значною мірою чутливі до характеру інфрормації, яку збирають про них компанії, що частково генерує перепони у поширенні ефективних цифррових рішень. Значна кількість водіїв не бажає поширювати приватну інформацію компаніям, особливо якщо йдеться про треті сторони, які застосовують відповідні дані для маркетингових цілей. Захист персональних споживчих даних також реалізовують відповідні закони, акти, які значно обмежують можливості збору та поширення приватної інформації як у цілях маркетингу, так і в цілях удосконалення ремонту чи виготовлення автомобілів. Необхідно зазначити, що обмеження на збір та використання даних суттєво відрізняються залежно від країни, у якій фрунціонує підприємство. Ураховуючи цей фракт, не всі виробники знаходяться в однакових умовах щодо монетизації даних, зібраних автотранспортним засобом. Попри це більшість споживачів (близько 40\%) схильна довіряти дані саме автовиробникам, аніж стороннім організаціям чи маркетинговим компаніям (близько 10\%).

4) Розвиток інорормаційних технологій завжди передбачає інтенсивне впровадження нового фунціоналу, можливостей для кооперації, удосконалення існуючих бізнес-процесів. Кожен споживач позитивно реагує на інформацію про внесення змін, удосконалення чи додавання нових фрункцій, i, беручи за приклад автотранспортний засіб, упровадження нових IT-рішень може дати змогу автовиробникам удосконалити асортимент послуг. Рішення, які впроваджуються, можуть базуватися на кооперації зі значною кількістю підприємств суміжних галузей, перелік яких висвітлено на рис. 2.
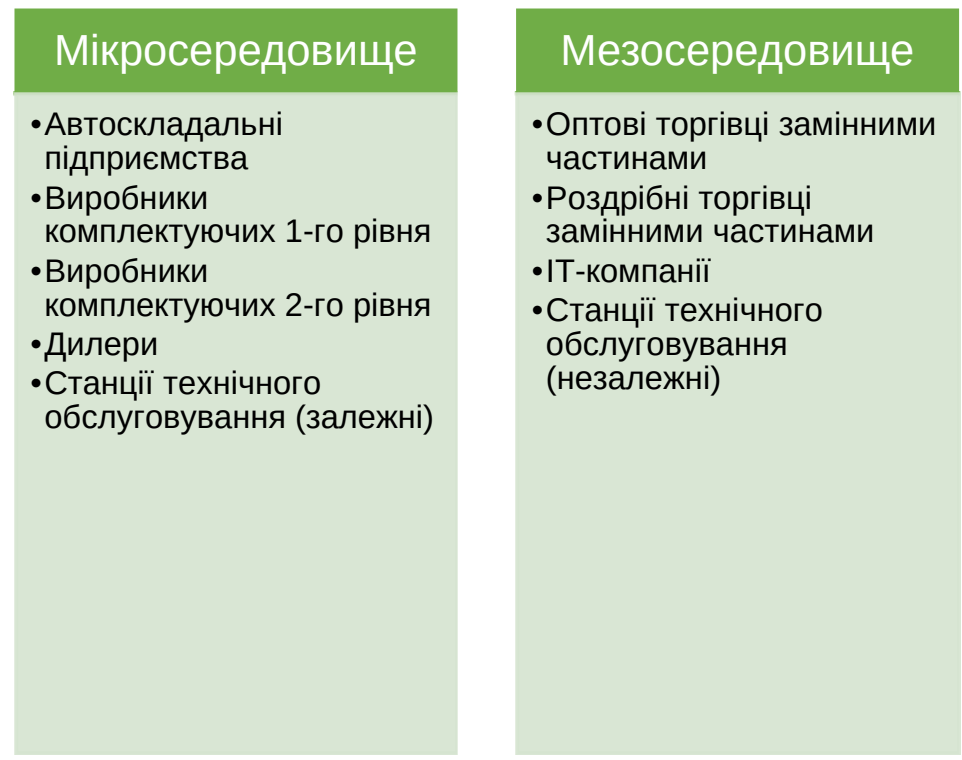

Макросередовище

- Страхові компанії

-Автодорожні компанії

-Логістичні компанії

-Лізингові компанії

-Державні установи

-Маркетингові агенції

-Ринки з продажу

автомобілів

- Маркетплейси

-Посередники

- Фінансові установи

-Автозаправні станції

- Інорраструктурні

оператори

-Мобільні оператори

-Державні установи

Рис. 2. Диференціація підприємств залежно від їхньої ролі у ланцюгу створення доданої вартості для споживачів автотранспортних засобів

Джерело: власна розробка автора 
Роль кожного з висвітлених на рисунку підприємств є різною залежно від життєвого циклу товару, підприємства чи споживача. Однак за умов ефрективного використання даних рішення можуть мати високий рівень КРI (показник ефективності реалізації завдання, від англ. key performance index). Необхідно також зазначити ризики у потенційній залежності автовиробників від великих компаній із розроблення програмного забезпечення, адже вибір автомобіля споживачем може стати не на підставі бренду автовиробника, а на підставі інформаційної платформи, яка є звичною для відповідного клієнта. У зв'язку із цим перед виробниками стоятиме завжди питання МOB (від анл. Make or Buy - виготовити чи купити).

5) Виокремлення в окремий елемент процесів антисипації нових можливостей залежно від життєвого циклу вказує на необхідність урахування різних стадій розвитку, а отже, різних очікувань і готовності до нововведень як із боку споживача, так і з боку автовиробника. Ідентифрікація корелюючих між собою фракторів, які вказують на потенційний розвиток певних подій у майбутньому, є одним із ключових елементів розвитку антисипативного маркетингу. Інфрормаційні технології мають надзвичайно короткий життєвий цикл, тому їх розроблення й упровадження повинні бути швидкими і доступними для будь-якого власника автомобіля (що уможливлюється завдяки технології ОТА (Over-the-air - від англ. «на ходу»).

6) Нові бізнес-моделі вже поступово впроваджуються всіма суб'єктами ланцюга створення цінності на ринку автотранспортних засобів. Вагомим поштовхом стали пандемія і зміна парадигм ведення бізнесу. Так, онлайн-торгівля стала нормою у більшості сорер діяльності, а доставка практично будь-якого товару є типовим процесом. За результатами дослідження компанії McKinsey's до 2025 р. практично чверть усіх трансакцій щодо купівлі автомобілів здійснюватиметься онлайн. Активна адаптація інформаційних технологій в автотранспортні засоби, значне зростання товарів із доступом до Інтернету дають основу для кращого розуміння потреб споживачів, зростання

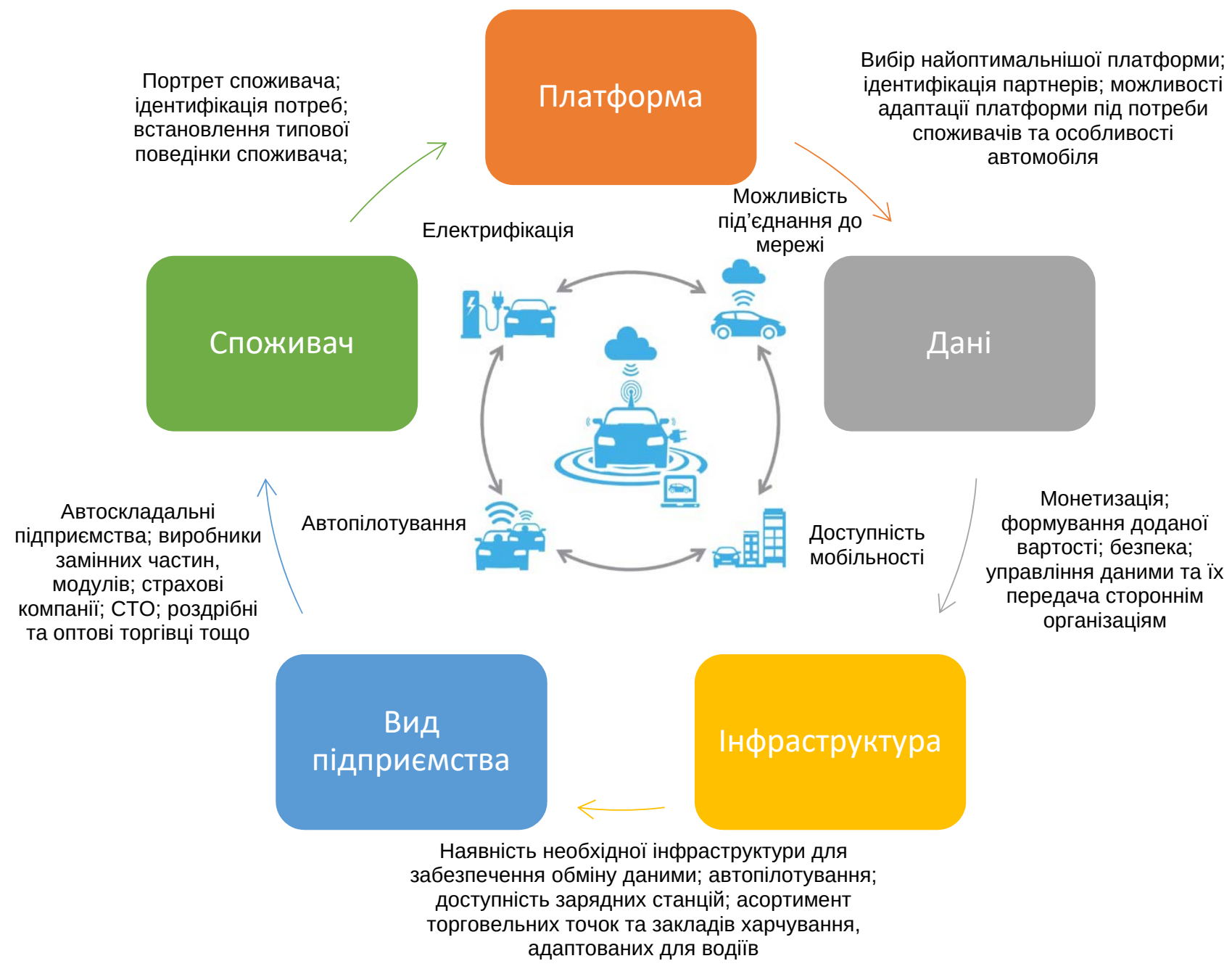

Рис. 3. Елементи, які здійснюють вплив на розвиток антисипативного маркетингу на ринку автомобілебудівних підприємств

Джерело: сфрормовано автором на підставі [5; 6] 
рівня комунікації, важливість лояльності до брендів стає більш значущою. Сучасні технології, такі як штучний інтелект, машинне навчання, використання хмарних баз даних, - усе це створює нові можливості для маркетингової діяльності та виокремлює нові вимоги до побудови маркетингових стратегій. Бізнес-моделі, які забезпечать ефективну монетизацію даних, стануть ключовими завданнями всіх активних суб'єктів на автомобілебудівному ринку.

Ефективна реалізація антисипативного маркетингу на підприємстві переважно залежить від:

- обсягів даних про споживача, його поведінку та їх багатогранності;

- уміння ідентифікації релевантних даних щодо поставлених цілей маркетингової кампанії;

- можливостей оперування даними про споживача, ураховуючи відповідні правові норми, які контролюють забезпечення приватності споживачів;

- експертності фрахівця, який приймає остаточні рішення;

- доступу до даних у суміжних галузях, що дає змогу забезпечити антисипацію потреб споживачів, тощо.

Успішна реалізація антисипативного маркетингу передбачає урахування таких кон'юнктурних елементів, які комплексно окреслюють завдання, що ставитимуться перед маркетологом (рис. 3).
Як видно з рисунку, сучасний автомобіль нерозривно поєднаний із навколишньою інфрраструктурою, тим самим забезпечуючи автовиробників цінною інформацією для ефективної монетизації маркетингових зусиль. Необхідно брати до уваги, що зі зміною автотранспортних засобів неодмінно відбуваються зміни й у поведінці споживачів, їхній досвід змінюється, а отже, і звички також зазнають корегувань, вимоги підвищуються, конкуренція на ринку розширюється. Зі збільшенням обсягів поширення інфрормації споживачами зростають їхні вимоги до безпеки інформації. Підприємства, які спеціалізуються на розробленні ІТ-рішень, логістичні компанії, компанії 3 обробки даних, великі маркетплейси стають важливими елементами авторинку. Попри динамічний розвиток сорери діджиталізації автотранспортних засобів та доступності уже значних обсягів даних про поведінку споживачів існують труднощі з її ефективним використанням та аналізом. Дані, які збираються, зазвичай використовуються як статистика без ґрунтовного аналізу кореляційних зв'язків, ідентифікації певних шаблонів, притаманних конкретному портрету споживача. Відповідно, можливості імплементації відповідних напрацювань значно звужуються, допоки компанії не розширять алгоритми обробки даних. На рис. 4 висвітлено рівень використання даних про споживача у процесі

Дані про погодні умови (туман, сніг, лід на дорозі тощо) та стан дороги (ремонт, наявність ям чи небезпечної ділянки)
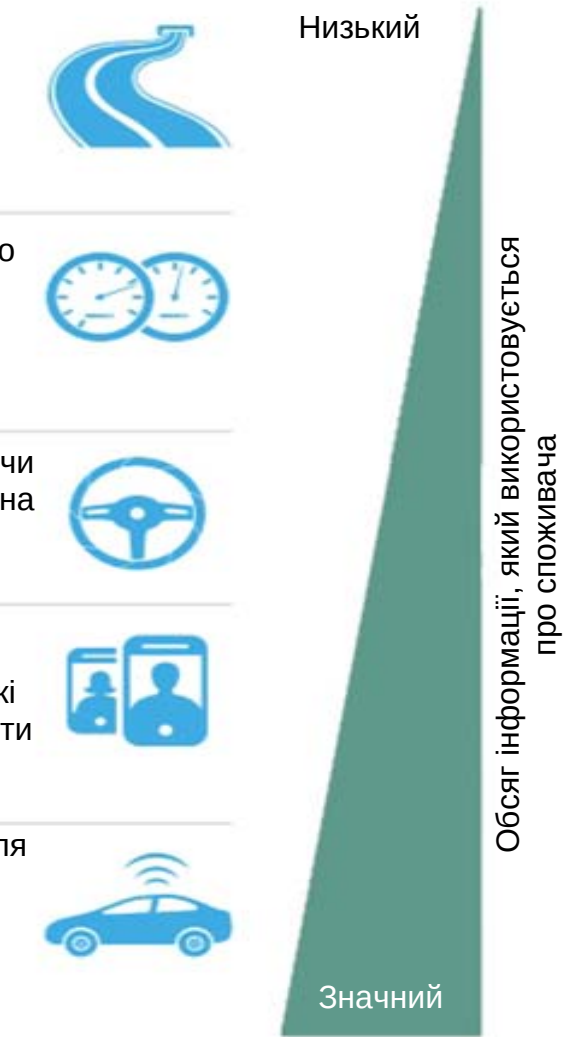

Технічний стан автомобіля, потреби щодо технічного огляду чи ремонту, рівень зносу замінних частин, можливості запису на огляд у найближчій станції технічного огляду

Стан використання автомобіля (швидкість, об'єм палива чи рівень заряду батареї, допустимий рівень навантаження на шасі, рівень використання масла тощо)

Персональна інформація та базуючись на даних індивідуалізовані пропозиції (оптимальних маршрутів, які зазвичай використовуються, інсрормація про години роботи закладів, які відвідуються тощо)

Організація прямої комунікації зі споживачем з автомобіля (повинен бути дозвіл на використання календаря, контактів, e-mail та іншої персональної інорормації для максимального забезпечення роботи механізмів антисипативного маркетингу)
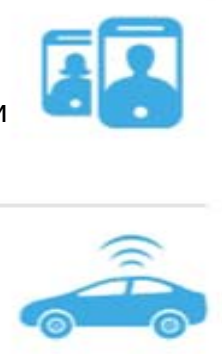

Рис. 4. Рівень використання даних про споживача у процесі реалізації цілей антисипативного маркетингу

Джерело: удосконалено автором на підставі [6] 
реалізації цілей антисипативного маркетингу. Досліджуючи чутливість споживачів до поширення інсрормації, можна підкреслити, що найбільш бажаними вигодами, які споживачі очікують отримати від поширення персональних даних, є:

- зменшення витрат на обслуговування автомобілів;

- збільшення рівня безпеки;

- поліпшення дорожньої інфрраструктури;

- удосконалення комунікаційних можливостей.

Таким чином, ураховуючи потреби споживачів та регуляторні обмеження на використання персональних даних, компанії можуть здійснювати вдосконалення існуючих алгоритмів аналізу, забезпечуючи при цьому достатній рівень цінності як для споживачів, так і для всіх суб'єктів ринку автотранспортних засобів. До ключових детермінантів, які створюють додану цінність як для споживача, так і для підприємства у процесі реалізації програми антисипативного маркетингу, можна віднести: зниження витрат, комерціалізацію продуктів та послуг, підвищення рівня безпеки на дорозі та захист персональних даних. На рис. 5 висвітлено їхні ключові характеристики.

Попри висвітлений вище потенціал розвитку антисипативного маркетингу, користуючись даними, зібраними автотранспортними засобами, масове поширення «розумних» автомобілів залишається одним з основних обмежувальних фракторів. Так, у найближчій перспективі ключовим ринком таких автомобілів стане Європа, зайнявши позицію США, проте, прогнозуючи тактично, ключовим ринком поступово ставатиме Китай. Існує декілька фракторів розвитку таких подій. Передусім рівень насиченості автомобілів у Китаї сьогодні не $€$ значним, а зростання доступності автомобілів із розширеними інформаційними технологіями тільки забезпечуватиме значний приріст такого характеру автомобілів. Другим фрактором, який стане причиною заміщення Китаєм ринку Європи, Є демографрічна структура населення. Старіння середньостатистичного споживача у Європі буде стримувати поширення відповідних інформаційних технологій (адже старшому населенню важче адаптовуватися до нових технологій) та, відповідно, сприятиме поширенню нових автомобільних технологій серед більш молодого середньостатистичного водія у Китаї [7]. Згідно 3 дослідженням компанії Capgemini, обсяг підключених до хмарних технологій автомобілів у Китаї становитиме близько 20\% усіх автомобілів такого характеру у світовому масштабі (рис. 6).

Також необхідно зазначити, що у даному прогнозі не враховувалися вживані автотранспортні

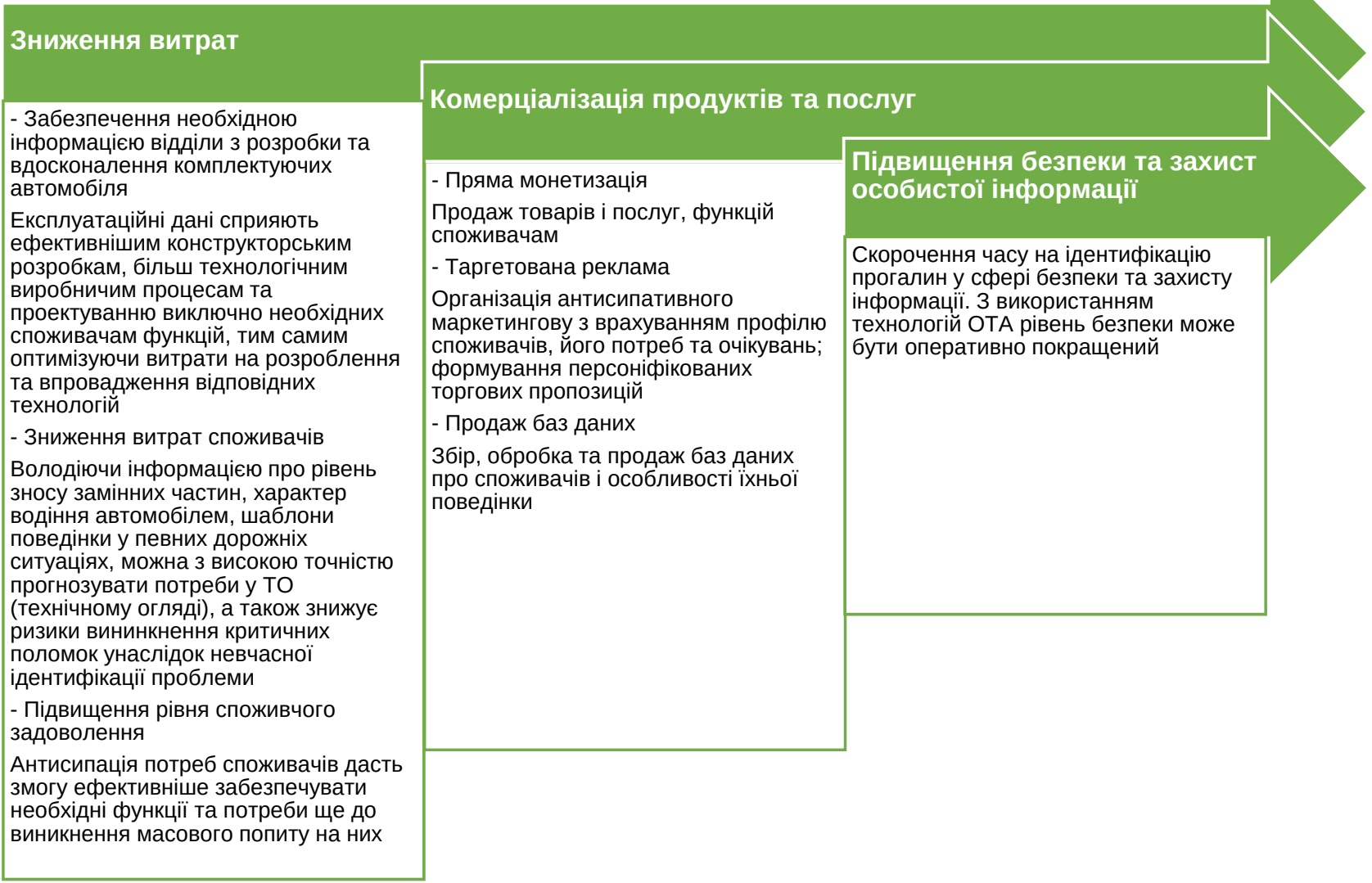

Рис. 5. Детермінанти доданої цінності у процесі реалізації програми антисипативного маркетингу 

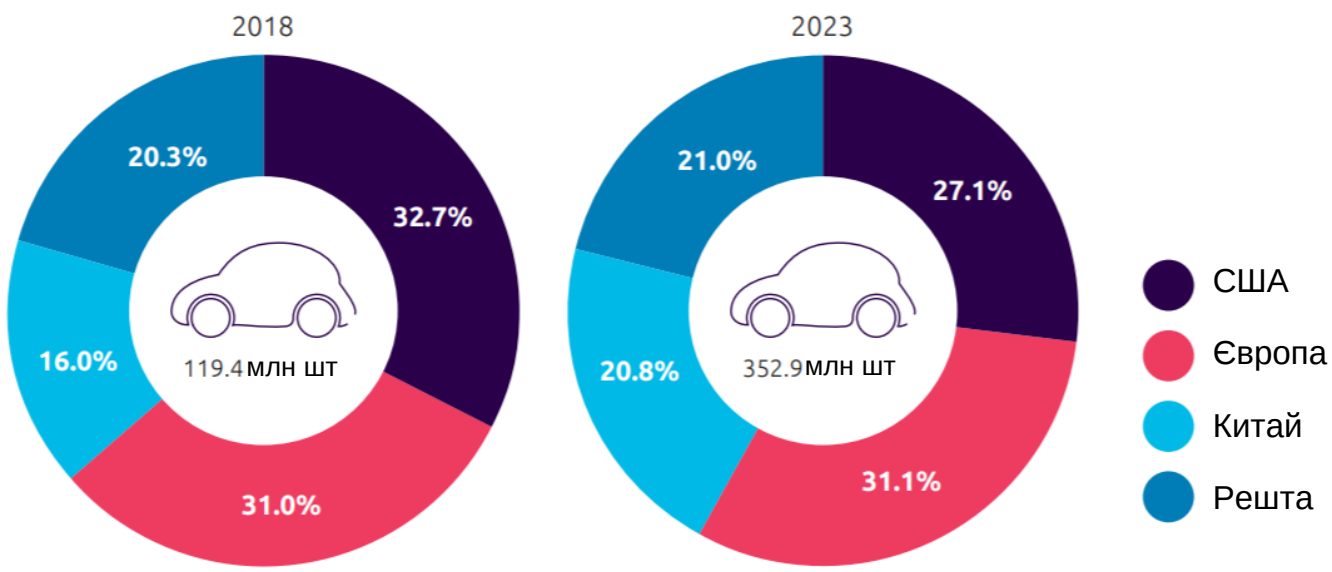

Рис. 6. Прогноз розвитку кількості автотранспортних засобів, які матимуть змогу підключення до хмарних технологій

Джерело: складено за [7]

засоби, які можуть бути обладнані відповідними датчиками та сенсорами за бажанням споживачів. За таких умов ринок матиме можливість не тільки подвоїтися, а й значно загострити питання забезпечення відповідними інорраструктурними рішеннями наявний автомобільний парк.

Висновки $з$ проведеного дослідження. Таким чином, попри пандемію, світову рецесію та відсутність стабільності подальший розвиток автомобілебудівного ринку буде спрямований на діджиталізацію, розвиток хмарних технологій, збільшення ролі штучного інтелекту та технологій машинного навчання у маркетингових процесах. ІТ-компанії значно збільшать обсяг доданої вартості, яку генеруватимуть для споживача нові можливості автомобілів, а отже, їхня роль на ринку суттєво зросте. Володіючи інорормацією про споживача такого масштабу, яку зможуть надавати автотранспортні засоби, можна поліпшити розуміння потреб споживачів, збільшити обізнаність про типові шаблони поведінки, підвищити рівень ефективності у комунікації з клієнтами. Поєднання онлайн- та офлайнданих про споживача, у тому числі й щодо суміжних галузей, дасть змогу забезпечити синергію даних та ефективно сформувати стратегію антисипативного маркетингу.

\section{БІБЛІОГРАФІЧНИЙ СПИСОК:}

1. McCarthy R., Halawi L. Applying Predictive Analytics. Springer International Publishing. 2020. P. 216.

2. Howard Hao-Chun, Ting-PengLiang Predictive Analytics for Customer Repurchase: Interdisciplinary Integration of Buy till You Die Modeling and Machine Learning. 2021. URL: https://www.sciencedirect.com/ science/article/abs/pii/S0377221721003350 (дата звернення: 25.04.2021).

3. Fergurson J. Ricky Data-driven decision making via sales analytics: introduction to the special issue. 2020. URL: https://link.springer.com/article/10.1057/s41 270-020-00088-2 (дата звернення: 27.04.2021).
4. Bertoncello M. Unlocking the full life-cycle value from connected-car data. 2021. URL: https://www.mckinsey.com/industries/automotive-andassembly/our-insights/unlocking-the-full-life-cycle-value-from-connected-car-data (датазвернення: 24.04.2021).

5. Deloitte. Journey through the future Connected cars and OEM outlook in India. 2020. URL: https://www2.deloitte.com/content/dam/Deloitte/in/Documents/consumer-business/in-consumer-Connected Cars-7july2020-noexp.pdf (дата звернення: 20.04.2021).

6. McKinsey\&Company. Monetizing car data: New service business opportunities to create new customer benefits. 2016. URL: https://www.mckinsey.com/ / media/mckinsey/industries/automotive\%20and\%20assembly/our\%20insights/monetizing\%20car\%20data/ monetizing-car-data.ashx (дата звернення: 20.04.2021).

7. Capgemini Invent. Connected vehicle trend radar .2019. URL: https://www.capgemini.com/wp-content/ uploads/2019/08/Connected-Vehicle-Trend-Radar.pdf (дата звернення: 20.04.2021).

\section{REFERENCES}

1. McCarthy R., Halawi L. (2020) Applying Predictive Analytics. Springer International Publishing. P. 216.

2. Howard Hao-Chun, Ting-PengLiang (2021) Predictive Analytics for Customer Repurchase: Interdisciplinary Integration of Buy till You Die Modeling and Machine Learning. Available at: https://www.sciencedirect.com/science/article/abs/pii/S0377221721003350 (accessed 25 April 2021).

3. Fergurson J. Ricky (2020) Data-driven decision making via sales analytics: introduction to the special issue. Available at: https://link.springer.com/article/ 10.1057/s41270-020-00088-2 (accessed 27 April 2021).

4. Bertoncello M. (2021) Unlocking the full lifecycle value from connected-car data. Available at: https://www.mckinsey.com/industries/automotive-andassembly/our-insights/unlocking-the-full-life-cycle-va lue-from-connected-car-data (accessed 24 April 2021).

5. Deloitte. (2020) Journey through the future Connected cars and OEM outlook in India. Available at: https://www2.deloitte.com/content/dam/Deloitte/in/ Doc- 
uments/consumer-business/in-consumer-ConnectedCars-7july2020-noexp.pdf (accessed 20 April 2021).

6. McKinsey\&Company (2016) Monetizing car data: New service business opportunities to create new customer benefits. Available at: https://www.mckinsey.com/ -/media/mckinsey/industries/automotive\%20and\%20 assembly/our\%20insights/monetizing\%20car\%20data/ monetizing-car-data.ashx (accessed 20 April 2021).

7. Capgemini Invent. (2019) Connected vehicle trend radar. Available at: https://www.capgemini.com/ wp-content/uploads/2019/08/Connected-Vehicle-TrendRadar.pdf (accessed 20 April 2021). 